\title{
Multiple Deficiency of Mucopolysaccharide Sulfatases in Mucosulfatidosis
}

\author{
R. BASNER, K. von FIGURA, J. GLÖSSL, U. KLEIN, H. KRESSE, AND W. MLEKUSCH \\ Institute of Physiological Chemistry, University of Münster, Münster, West Germany (R. B., K. v. F., U. K.) and \\ Institute of Medical Chemistry, University of Graz, Graz, Austria (J. G., H. K., W. M.)
}

\begin{abstract}
Summary
Fibroblasts of four patients affected with mucosulfatidosis (multiple sulfatase deficiency, Austin variant of metachromatic leukodystrophy) were assayed for activities of the five sulfatases known to degrade mucopolysaccharides. These were iduronide 2-sulfate sulfatase, sulfamidase, $\mathrm{N}$-acetyl-galactosamine 6 -sulfate sulfatase, arylsulfatase B ( $N$-acetylgalactosamine 4-sulfate sulfatase), and $\boldsymbol{N}$-acetylglucosamine 6 -sulfate sulfatase. The activities of these five sulfatases were severely depressed, thus confirming the known deficiency of arylsulfatase $B$ and the absence of the Hunter and Sanfilippo III A corrective factors that have iduronide 2-sulfate sulfatase and sulfamidase activity, respectively.

Together with earlier reports on the deficiencies of arylsulfatases $A$ and $C$, cholesteryl sulfatase, and dehydroepiandrosterone sulfatae, mucosulfatidosis is now characterized by the deficiency of nine different sulfatases.

\section{Speculation}

Mucosulfatidosis is a disease characterized by the deficiency of multiple sulfatases in cultured fibroblasts in contrast to the deficiencies of singe sulfatases that are known for the five mucopolysaccharide degrading sulfatases and arylsulfatase $A$. The genes responsible for the expression of the sulfatases are located both on autosomes and the X-chromosomes. Mucosulfatidosis fibroblasts should provide an experimental model for the study of a hitherto unknown common mechanism responsible for the expression of sulfatase activities.
\end{abstract}

Mucosulfatidosis is a lysosomal storage disease characterized by the storage of sulfatides, glycosaminoglycans, and steroid sulfates. The storage is caused by the deficiency of multiple sulfatases (for review, see refs. 1 and 2 ). In fibroblasts and tissues so far the deficiency of arylsulfatases A, B, and C, cholesteryl sulfatase and dehydroepiandrosterone sulfatase are known $(3,4)$. It is, however, still unclear whether activities of arylsulfatase $C$ and the steroid sulfatases reside in the same enzyme or whether different enzymes catalyze these reactions (2). Furthermore, mucosulfatidosis fibroblasts do not correct the deranged mucopolysaccharide catabolism in fibroblasts derived from patients affected with Hunter or Sanfilippo A syndrome which implies that mucosulfatidosis fibroblasts are deficient in iduronide 2-sulfate sulfatase and sulfamidase (5). Thus, mucosulfatidosis is characterized by the deficiency of lysosomal and microsomal sulfatases (arylsulfatase C) that are coded by autosomal and $\mathrm{X}$-chromosomal (iduronide 2 -sulfate sulfatase) genes.

Recently, two new mucopolysaccharide degrading sulfatases have been described, $\mathrm{N}$-acetylgalactosamine 6-sulfate sulfatase (68 ) and $\mathrm{N}$-acetylglucosamine 6 -sulfate sulfatase $(8,9)$. Both $\mathrm{N}$ acetylhexosamine 6-sulfate sulfatases act also on the corresponding hexose 6-sulfates, i.e., galactose 6-sulfate and glucose 6-sulfate, respectively. The activities of these two sulfatases and those of iduronide 2-sulfate sulfatase, sulfamidase, and arylsulfatase B $(\mathrm{N}-$ acetylgalactosamine 4-sulfate sulfatase) were assayed in four mucosulfatidosis fibroblast lines using natural substrates.

\section{MATERIALS AND METHODS}

\section{MATERIALS}

Heparin- $\mathrm{N}^{35} \mathrm{SO}_{4}$, specific activity $15 \mu \mathrm{Ci} / \mathrm{mg}$, was obtained from Amersham Buchler, Braunschweig, Heparin from Serva, Heidelberg, P-nitrophenyl- $\beta$-D-glucuronide and P-nitrophenyl- $\beta$ D-galactoside from Koch-Light, Colnbrook. The disulfated disaccharide L-iduronosyl 2 sulfate- $\left[1-{ }^{3} \mathrm{H}\right]$ anhydromannitol 6 -sulfate (specific activity $10 \mathrm{mCi} / \mathrm{mmole}$ ) prepared from heparin $(10)$ uridine diphosphate (UDP)-N-acetylglucosamine 4-[ ${ }^{35}$ S]sulfate (specific activity $27 \mathrm{mCi} / \mathrm{mmole}$ ) from hen oviduct (10), the monosulfated tri-saccharide N-acetylgalactosamine 6-sulfate (GlcNAC (6S)) D-glucuronic acid (GlcUA)-[1- $\left.{ }^{3} \mathrm{H}\right]$ anhydromannitol (specific activity $68.8 \mathrm{mCi} / \mathrm{mmole}$ ) prepared from heparin sulfate (9), and the disulfated trisaccharide GalNAc(6S)-GlcUA$\mathrm{N}$-acetyl-[1- $\left.{ }^{3} \mathrm{H}\right]$ galactosaminitol $(6 \mathrm{~S})$ (specific activity $24.9 \mathrm{mCi}$ / mmole) prepared from chondroitin 6-sulfate (12) were obtained as described.

\section{PATIENTS}

Skin biopsies or fibroblast cultures from patients with mucosulfatidosis were kindly provided by Drs. J. Couchot (Reims), cell line 1, U. Wiesmann (Bern), cell line 2, and M. Niermeijer (Rotterdam), cell line 3. Cell line 4 (GM 2407), was obtained from the Human Genetic Mutant Cell Repository, Camden, N.J.

\section{METHODS}

Cell Culture. Human skin fibroblasts from normal individuals and from patients of various genotypes were cultured in $25 \mathrm{~cm}^{2}$ Falcon plastic flasks with Eagle's Minimal Essential Medium (18) containing $10 \%$ fetal calf serum (LS-Labor Service, München), nonessential amino acids, and antibiotics as described previously (14). Cultures grown to confluency were harvested by trypsinization, the cells were washed twice with $0.15 \mathrm{M} \mathrm{NaCl}$, and cell suspensions in $0.2 \mathrm{ml} 0.15 \mathrm{M} \mathrm{NaCl}$ were made by ten cycles of freezing and thawing. For the assay of $\mathrm{N}$-acetylgalactosamine 6sulfate sulfatase, the cells were suspended in water and homogenized by ultrasonication.

Assays. Assay of iduronide 2-sulfate sulfatase (modification of 10): The standard reaction mixture contained in a final volume of $40 \mu 116$ nmole disulfated disaccharide, $0.125 \mathrm{M}$ sodium acetate, pH $3.8,0.013 \% \mathrm{NaN}_{3}$ and $30 \mu \mathrm{l}$ cell suspension that had been dialyzed at $4^{\circ} \mathrm{C}$ for $24 \mathrm{hr}$ against 5 liters of $0.15 \mathrm{M} \mathrm{NaCl}$. After incubation for $48 \mathrm{hr}$ at $37^{\circ} \mathrm{C}$, the reaction mixture was analyzed by high voltage electrophoresis at $\mathrm{pH} 1.7$ on Whatman $3 \mathrm{MM}$ 
paper. Electrophoresis was carried out for $60 \mathrm{~min}$ at $40 \mathrm{~V} / \mathrm{cm}$ in $1.9 \mathrm{M}$ formic acid. The electropherogram was cut into $1 \times 2 \mathrm{~cm}$ strips, that were placed in scintillation vials and eluted with $1 \mathrm{ml}$ of water before the addition of $2 \mathrm{ml}$ Unisolve 1 (Zinsser, Frankfurt) as scintillation medium.

Assay of heparin sulfamidase: The standard reaction mixture contained about $85000 \mathrm{cpm}$ heparin- $\mathrm{N}_{-}^{35} \mathrm{SO}_{4}$, corresponding to 21 nmole sulfamino groups, $0.14 \mathrm{M}$ sodium acetate, $\mathrm{pH} 5.0,0.03 \%$ $\mathrm{NaN}_{3}(\mathrm{w} / \mathrm{v}), 0.016 \%$ bovine serum albumin (w/v), and $30 \mu \mathrm{l}$ cell suspension in a final volume of $80 \mu \mathrm{l}$. After 3-5 hr, the reaction mixture was diluted to $0.5 \mathrm{ml}$ with $0.3 \mathrm{M} \mathrm{NaCl}$ and loaded onto a $0.5 \times 3 \mathrm{~cm}$ column of Ecteola 23 (Serva, Heidelberg), equilibrated in water. The column was washed with $7.5 \mathrm{ml}$ of $0.3 \mathrm{M}$ $\mathrm{NaCl}$. The liberated ${ }^{35} \mathrm{SO}_{4}$ was eluted with the first $4 \mathrm{ml}$ of $0.3 \mathrm{M}$ $\mathrm{NaCl}$. Radioactivity was determined after addition of an equal volume of Unisolve 1.

Assay of N-acetylgalactosamine 6-sulfate sulfatase: The reaction mixture contained 0.46 nmoles disulfated trisaccharide GalNAc(6S)- GlcUA - N-acetyl- $\left[1-{ }^{3} \mathrm{H}\right]$ galactosaminitol $(6 \mathrm{~S}), \quad 100$ $\mathrm{mM}$ sodium acetate, $\mathrm{pH} 4.8$, and $25 \mu \mathrm{l}$ cell suspension in a final volume of $60 \mu \mathrm{l}$. After incubation for $1-2 \mathrm{hr}$, the reaction mixture was loaded onto a $0.5 \mathrm{ml}$ column of Dowex $1 \times 2,200-400$ mesh, and enzyme activity was determined as described (12).

Assay of UDP-4-sulfo- $\mathrm{N}$-acetylgalactosamine sulfatase (arylsulfatase B): The standard reaction mixture contained 60 pmole UDP-4-[ $\left[{ }^{35} \mathrm{~S}\right]$ sulfo-N-acetyl-galactosamine, $50 \mathrm{mM}$ sodium acetate buffer, pH 3.3, $0.01 \%$ bovine serum albumin, $10 \mathrm{mM}$ dithiothreitol, and $20 \mu \mathrm{l}$ cell suspension in a final volume of $0.1 \mathrm{ml}$. After $\mathrm{l} \mathrm{hr}$, the reaction was stopped by addition of $0.1 \mathrm{ml} / \mathrm{M} \mathrm{HCl}$ containing $2.5 \mathrm{mg}$ charcoal. After $10 \mathrm{~min}$, the reaction mixture was filtered into a scintillation vial. The filter was washed five times with 0.1 $\mathrm{ml} 0.5 \mathrm{M} \mathrm{HCl}$, thus, eluting completely the liberated $\left[{ }^{35} \mathrm{~S}\right]$-sulfate. After addition of $15 \mathrm{ml} \mathrm{2.1 \%} \mathrm{2,5} \mathrm{Diphenyloxazole} \mathrm{and} 0.026 \% 1,4$ bis[2(4-methyl-5-phenyl-oxazole)]benzene in toluene/ethylmonomethyl ether $1: 1$ (v:v) the radioactivity was determined.

Assay of $\mathrm{N}$-acetylglucosamine 6-sulfate sulfatase: The incubation mixture contained 220 pmole monosulfated trisaccharide GlcNAc(6S)-GlcUA-[1- $\left.{ }^{3} \mathrm{H}\right] \mathrm{aManol}$ in $0.16 \mathrm{M}$ sodium acetate, $\mathrm{pH}$ $5.5,0.017 \%(\mathrm{w} / \mathrm{v})$ bovine serum albumin, $0.03 \%(\mathrm{w} / \mathrm{v}) \mathrm{NaN}_{3}$, and $5 \mu \mathrm{l}$ cell homogenate in a total volume of $6 \mu \mathrm{l}, 5 \mu \mathrm{l}$ paraffin oil were layered on the incubation mixture. After incubation for 16 $20 \mathrm{hr}$ at $37^{\circ} \mathrm{C}$, the formation of unsulfated ${ }^{3} \mathrm{H}$-material was determined by a previously described microcolumn procedure (9).

Assays of $\beta$-glucuronidase and $\beta$-galactosidase: The reaction mixtures contained $5 \mathrm{mM}$ P-nitrophenyl glycosides, $50 \mathrm{mM}$ sodium citrate, $\mathrm{pH} 4.6,0.1 \%$ bovine serum albumin (w/v), $0.02 \%$ $\mathrm{NaN}_{3}(\mathrm{w} / \mathrm{v})$, and 5-10 $\mu \mathrm{l}$ of cell suspension in a final volume of $0.2 \mathrm{ml}$. The incubation time for $\beta$-galactosidase was $30-90 \mathrm{~min}$ and that for $\beta$-glucuronidase $18-20 \mathrm{hr}$. The incubation was ter- minated by addition of $1.0 \mathrm{ml} 0.4 \mathrm{M}$ glycine/ $\mathrm{NaOH}$ buffer $\mathrm{pH}$ 10.4 and absorbance was read at $405 \mathrm{~nm}$.

Other methods: The protein content of cell suspension (15) and sulfamino groups in heparin (16) were determined as described. Radioactivity was determined in a B 2450 (Packard, Frankfurt) liquid scintillation spectrometer.

\section{RESULTS}

The activities of iduronide 2-sulfate sulfatase, heparin sulfamidase, $\mathrm{N}$-acetylgalactosamine 6-sulfate sulfatase, UDP-N-acetylgalactosamine 4-sulfate sulfatase and $\mathrm{N}$-acetylglucosamine 6-sulfate sulfatase were markedly reduced or not detectable in fibroblast homogenates of four patients affected with mucosulfatidosis (Table 1). The residual enzyme activities of iduronide 2-sulfate sulfatase, UDP-N-acetylgalactosamine 4-sulfate sulfatase, and $\mathrm{N}$-acetylglucosamine 6-sulfate sulfatase were comparable to those in single sulfatase deficiencies (not shown), whereas sulfamidase and $\mathrm{N}$-acetylgalactosamine 6-sulfate sulfatase activities were up to nine and three times higher than in the Sanfilippo syndrome type $\mathbf{A}$ and the classical Morquio syndrome, respectively. The activities of arylsulfatase $A$ and arylsulfatase $B$ (measured with P-nitrocatechol sulfate) were below $10 \%$ of controls (not shown). The activities of $\beta$-glucuronidase and $\beta$-galactosidase were in the range of controls.

\section{DISCUSSION}

So far, six lysosomal storage diseases are known to be caused by single sulfatase deficiencies. Metachromatic leukodystrophy is characterized by the absence of arylsulfatase $A(17,18)$, thus, leading to the storage of sulfatides. The mucopolysaccharidoses II (Hunter syndrome), III A (Sanfilippo syndrome type A), IV (Morquio syndrome), VI (Maroteaux-Lamy syndrome), and VIII are caused by the deficiencies of iduronide 2-sulfate sulfatase (19), sulfamidase (20), $\mathrm{N}$-acetylgalactosamine 6 -sulfate sulfatase $(6,7)$, $\mathrm{N}$-acetylgalactosamine 4-sulfate sulfatase (11, 21-23), and $\mathrm{N}$-acetylglucosamine 6-sulfate sulfatase (8). The stored mucopolysaccharides comprise dermatan sulfate, heparan sulfate, and keratan sulfate. Secondary storage of glycolipids is frequently observed due to the inhibition of lysosomal hydrolases involved in glycolipid degradation by stored mucopolysaccharides (24).

The unique feature of mucosulfatidosis is the inactivity of multiple sulfatases. The present report extends the number of deficient sulfatases to seven or nine depending upon whether steroid sulfatases and arylsulfatase $C$ are identical or not. The only sulfatase activity detected so far in mucosulfatidosis was directed against 3 '-phosphoadenosine-5' -phosphosulfate (25). This multiple sulfatase deficiency explains the heterogeneity of the

Table 1. Sulfatase and glycosidase activities in control and mucosulfatidosis fibroblasts ${ }^{1}$

\begin{tabular}{|c|c|c|c|c|c|}
\hline \multirow{2}{*}{ Enzyme } & \multicolumn{4}{|c|}{ Mucosulfatidosis cell lines } & \multirow{2}{*}{ Control fibroblasts } \\
\hline & 1 & 2 & 3 & 4 & \\
\hline Iduronide 2-sulfate sulfatase & n.d. ${ }^{2}$ & 0.012 & 0.017 & 0.006 & $1.6(0.53-5.54)$ \\
\hline Sulfamidase & 0.12 & 0.05 & 0.15 & 0.05 & $\begin{array}{l}1.9(0.9-4.5) \\
(n=18)\end{array}$ \\
\hline $\begin{array}{l}\mathrm{N} \text {-Acetylgalactosamine 6-sulfate sulfa- } \\
\text { tase }\end{array}$ & 0.025 & 0.014 & 0.053 & n.d. & $\begin{array}{l}0.41(0.26-0.56) \\
(n=12)\end{array}$ \\
\hline $\begin{array}{l}\text { UDP-N-Acetylgalactosamine } 4 \text {-sulfate } \\
\text { sulfatase }\end{array}$ & 0.02 & 0.07 & 0.04 & 0.05 & $\begin{array}{l}0.91(0.43-1.28) \\
(n=8)\end{array}$ \\
\hline $\begin{array}{l}\mathrm{N} \text {-Acetylglucosamine } 6 \text {-sulfate sulfa- } \\
\text { tase }\end{array}$ & 0.005 & 0.006 & 0.004 & n.d. & $\begin{array}{l}0.18(0.08-0.32) \\
(n=21)\end{array}$ \\
\hline$\beta$-Galactosidase & 1410 & 1272 & 1896 & 1032 & $\begin{array}{l}1620(264-4020) \\
(n=12)\end{array}$ \\
\hline$\beta$-Glucuronidase & 234 & 66 & 192 & 78 & $\begin{array}{l}102(60-180) \\
(n=5)\end{array}$ \\
\hline
\end{tabular}

\footnotetext{
'Activity is expressed as nmole substrate splitted at $37^{\circ} \mathrm{C} / \mathrm{hr}$ and $\mathrm{mg}$ cell protein.
}

${ }^{2}$ n.d.: not detectable. 
primary storage material, comprising sulfatides, sulfated mucopolysaccharides, and steroid sulfates $(1,2)$. An intriguing fact is that sulfatases are lacking that are intra- and extralysosomally located and that are coded by autosomal and $\mathrm{X}$-chromosomal genes.

Several explanations can be put forward to explain the multiple sulfatase deficiency in mucosulfatidosis: for example, mutation of a subunit common to the deficient sulfatases, mutation of a gene controlling the expression of the deficient sulfatases, absence of a common activator, or presence of a common inhibitor. Previous attempts to demonstrate a common activator or inhibitor $(H$. Kresse, K. von Figura, unpublished results) failed. The mutation of a regulatory gene appears to be unlikely because material crossreacting with monospecific antibodies against arylsulfatase $\mathbf{A}$ could be demonstrated in the liver of a mucosulfatidosis patient (26). Attempts to reactivate activities of sulfamidase and arylsulfatase A by mixing homogenates from mucosulfatidosis fibroblasts with those from either mucopolysaccharidosis III A or metachromatic leukodystrophy in the presence of high salt or urea concentrations, which are supposed to facilitate subunit exchange failed, nor was reactivation of arylsulfatase $A$ observed when purified human sulfamidase and homogenates from mucosulfatidosis fibroblasts were mixed under analogous conditions. Furthermore, fusion experiments yielding bikaryotic cells containing both the genome of mucosulfatidosis fibroblasts and that of either metachromatic leukodystrophy or Maroteaux-Lamy or Sanfilippo A fibroblasts, respectively, failed to show an increase in arylsulfatase A or arylsulfatase B or sulfamidase activities or a significant decrease in radiosulfate incorporation in the fusion experiments with the mucopolysaccharidoses cell lines $(H$. Kresse, K. von Figura, K. H. Grezschik, unpublished results).

Recently, Fluharty et al. reported the raise of arylsulfatase A levels to almost control values, when mucosulfatidosis fibroblasts were grown in HEPES instead of $\mathrm{CO}_{2}$ buffered medium (27) suggesting that the defect in mucosulfatidosis may be reversed by environmental factors. Though all attempts have failed so far to explain the basis of the multiple sulfatase deficiency, mucosulfatidosis represents an extremely interesting model for the understanding of the expression and regulation of sulfatase in man.

\section{REFERENCES AND NOTES}

I. Austin. J.: Metachromatic leukodystrophy (Sulphatide Lipidosis). In: H. G. Hers, and F. van Hoof: Lysosomes and Storage Diseases pp. 411-437. (Academic Press, New York, London, 1973).

2. Dulaney, J. T., and Moser. H. W.: Sulfatide lipidosis: Metachromatic leukodystrophy. In: J. B. Stanbury, J. B. Wyngaarder, and D. S. Fredrickson: The Metabolic Basis of Inherited Disease pp. 770-809, 4th Edition. (McGraw Hill, New York, 1978).

3. Austin, J., Armstrong, D., and Shearer, L.: Metachromatic form of diffuse cerebral sclerosis. V. The nature and significance of low sulfatase activity: A controlled study of brain, liver and kidney in four patients with metachromatic leukodystrophy (MLD). Arch. Neurol., 13: 593 (1965).

4. Murphy, J. V., Wolfe. H. J.. Balazs, E. A., and Moser, H. W.: A patient with deficiency of arylsulfatases A, B, C and steroid sulfatase, associated with storage of sulfatide, cholesterol sulfate and glycosaminoglycans. In: J. Bernsohn, H. J. Grossman: Lipid Storage Diseases: Enzymatic Defects and Clinical Implications pp. 67-110 (Academic Press, New York, 1971).

5. Eto, Y., Wiesmann, U. N., Carson, J. H., and Herschkowitz, N. N.: Multiple

Copyright (c) 1979 International Pediatric Research Foundation, Inc $0031-3998 / 79 / 1312-1316 \$ 02.00 / 0$ sulfatase deficiencies in cultured skin fibroblasts. Occurence in patients with a variant form of metachromatic leukodystrophy. Arch. Neurol., 30: 153 (1974).

6. Matalon. R., Arbogast, B., Justice, P.. Brandt. E. K.. and Dorfman, A.: Morquio's syndrome: Deficiency of a chondroitin sulfate $\mathrm{N}$-acetylhexosamine sulfate sulfatase. Biochem. Biophys. Res. Commun., 61: 759 (1974).

7. Singh, J., DiFerrante, N., Niebes, P., and Tavella, D.: N-Acetylgalactosamine 6sulfate sulfatase in man. Absence of the enzyme in Morquio disease. J. Clin Invest., 57: 1036 (1976).

8. DiFerrante, N., Ginsberg, L. C., Donnelly, P. V., DiFerrante. D. F., and Caskey, C. T.: Deficiencies of glucosamine 6-sulfate or galactosamine 6-sulfate sulfatases are responsible for different mucopolysaccharidoses. Science. 199: 79 (1978).

9. Basner, R., Kresse. H., and von Figura, K.: N-Acetylglucosamine 6-sulfate sulfatase from human urine. J. Biol. Chem., 254: 5 (1979).

10. Lim, T. W. Leder, I. G., Bach, G., and Neufeld, E. F.: An assay for iduronate sulfatase (Hunter corrective factor). Carbohydrate Res.. 37: 103 (1974).

11. Fluharty, A. L., Stevens, R. L., Fung. D., Peak, S., and Kihara, H.: Uridine diphospho-N-acetylgalactosamine 4-sulfate sulfohydrolase activity of human arylsulfatase B and its deficiency in the Maroteaux-Lamy syndrome. Biochem. Biophys. Res. Commun., 64: 955 (1975).

12. Glösl, J., and Kresse, H.: A sensitive procedure for the diagnosis of $\mathrm{N}$-acetylgalactosamine 6-sulfate sulfatase deficiency in classical Morquio's disease. Clin. Chim. Acta, 88: 111 (1978).

13. Eagle, H.: Amino acid metabolism in mammalian cell cultures. Science, 130: 432 (1959).

14. Cantz, M., Kresse, H., Barton, R. W., and Neufeld. E. F.: Corrective factors for inborn errors of mucopolysaccharide metabolism. In: V. Ginsburg: Methods in Enzymology Vol. 28, pp 884-897 (Academic Press, New York, London. 1972).

15. Kaltwasser, F. Wolter, P., and Pieper, J.: Kolorimetrische mikromethode zur Bestimmung des Gesamteiweisses in eiweissarmen Flüssigkeiten. Clin. Chim. Acta, 15: 347 (1967)

16. Dische, Z., and Borenfreund, E.: A spectrophotometric method for the micro determination of hexosamines. J. Biol. Chem., 184: 517 (1950).

17. Austin, J., Balasubramanian, A., Pattabiraman, T., Saraswathi, S., Basu, D., and Bachhawat. B. K.: A controlled study of enzyme activities in three human disorders of glycolipid metabolism. J. Neurochem., 10: 805 (1963).

18. Austin, J. McAfee, D. Armstrong, D. O'Rourke, M., Shearer, L., and Bachhawat, B.: Abnormal sulphatase activities in two human diseases (metachromatic leukodystrophy and gargoylism) Biochem. J., 93: 15c (1964).

19. Bach, G., Eisenberg. F., Jr., Cantz, M., and Neufeld, E. F.: The defect in Hunter syndrome: Deficiency of sulfoiduronate sulfatase. Proc. Nat. Acad. Sci. USA., 70: 2134 (1973).

20. Kresse, H.: Mucopolysaccharidosis III A (Sanfilippo disease): Deficiency of heparin sulfamidase in skin fibroblasts and leukocytes. Biochem. Biophys. Res. Commun., 54: 1111 (1973).

21. Stumpf, D. A., Austin, J. H., Crocker, A. C., and LaFrance, M.: Mucopolysaccharidosis type VI (Maroteaux-Lamy syndrome). Am. J. Dis. Child., 126: 747 (1973).

22. O'Brien, J. F., Cantz, M., and Spranger, J.: Maroteaux-Lamy disease (mucopolysaccharidosis VI), subtype A: deficiency of a $\mathrm{N}$-acetylgalactosamine 4-sulfatase. Biochem. Biophys. Res. Commun., 60: 1170 (1974).

23. Matalon, R., Arbogast, B., and Dorfman, A.: Deficiency of a chondroitin sulfate $\mathrm{N}$-acetylgalactosamine 4-sulfate sulfatase in Maroteaux-Lamy syndrome. Biochem. Biophys. Res. Commun., 61: 1450 (1974).

24. Kint, J. A., Dacremont, G., Carton, D.. Orye, E. and Hooft, C.: Mucopolysaccharidoses: secondarily induced abnormal distributions of lysosomal isoenzymes. Science, 181: 352 (1973).

25. Stumpf, D. A., and Austin, J. H.: Qualitative and quantitative differences in sulfatase $A$ in different forms of classical metachromatic leukodystrophy. In: J. Bernsohn and H. J. Grossman: Lipid Storage Diseases: Enzymatic Defects and Clinical Implications pp. 203-241 (Academic Press. New York, 1971).

26. Stumpf, D., Neuwelt, E., Austin, J., and Kohler, P.: Metachromatic leukodystrophy (MLD). X. Immunological studies of the abnormal sulfatase A. Arch. Neurol., 25: 427 (1971).

27. Fluharty, A. L., Stevens, R. L., Davis, L. L.. Shapiro, L. J., and Kihara, H.: Presence of arylsulfatase A (ARS A) in multiple sulfatase deficiency disorder fibroblasts. Am. J. Hum. Genet., 30: 249 (1978).

28. The authors thank Mrs. G. Hess for excellent technical help.

29. This research was supported by the Deutsche Forschungsgemeinschaft (SFB 104) and the Fonds zur Förderung der wissenschaftlichen Forschung in Österreich.

30. Received for publication November 15,1978

31. Accepted for publication January 8, 1979. 